\title{
"To Live" with Bureaucracy and Looking at Bureaucracy from the "Castle"
}

Bürokrasiyle "Yaşamak” ve Bürokrasiye "Şato”dan Bakmak

\section{Dilek ŞAHIN}

Doktorant, Ankara Hacı Bayram Veli Üniversitesi,

SBE, Siyaset Bilimi ve Kamu Yönetimi A.B.D.,

d_sahinn@yahoo.com

https://orcid.org/0000-0002-8879-0830
Makale Başvuru Tarihi: 18.08.2020

Makale Kabul Tarihi: 24.12.2020

Makale Türü: Araştırma Makalesi
Anahtar

Kelimeler:

Bürokrasi,

Bürokrasi

Kuramlarl,

Şato,

Yaşamak,

Yönetim,

Keywords:

Bureaucracy,

Theories of

Bureaucracy,

The Castle,

To Live (Ikiru),

Administration,

\section{ÖZET}

Bu çalışmadaki temel amaç, bürokrasi kavramının ortaya çıkışı, gelişimi, farklı toplumsal yapılardaki konumu ve dönüşümünü Akira Kurosawa'nın yönettiği "Ikiru (yaşamak)" filmi ve Franz Kafka'nın "Şato" romanı üzerinden ele alarak bürokrasinin farklı yönlerini ortaya koymaktır. Bu amaç doğrultusunda öncelikle, "bürokrasi" kavramının tanımı ve kökeni ortaya konulmakta; bürokrasi kuramlarına değinilmektedir. Bu çalışmada, tarihsellik bağlamı içinde gelişim ve dönüşüme uğrayan "bürokrasi” olgusu, bürokratik yönetim biçiminin işleyişi, karar alma süreci, iş bölümü, otorite, hiyerarşi, yetki devri vb. alanlardaki somut görüntüsü üzerinden incelenmiştir. İnceleme, söz konusu gelişimin tohumlarının atıldığı ve dönüşümün yaşandiğ dönemlerde oluşan ve gelenekselleşen yapının nedenlerini "Ikiru" filmi ve "Şato" romanı üzerinden anlamak açısında da önem arz etmektedir.

\begin{abstract}
The main purpose of this study is to reveal different aspects of the bureaucracy by addressing the emergence of the concept of bureaucracy, its development, its position and transformation in different social structures analyzing the movie "Ikiru (to live)" directed by Akira Kurosawa and "Das Schloss (the Castle)" by Franz Kafka. In line with this purpose, firstly, the definition and origin of the concept of "bureaucracy" is introduced and theories of bureaucracy are mentioned. In this study, the phenomenon of "bureaucracy", which has undergone development and transformation within the context of historicity, has been examined over the concrete image in the fields like the functioning of the bureaucratic form of administration, decisionmaking process, division of labor, authority, hierarchy, delegation of authority, etc. The analysis is also important in terms of understanding the reasons for the structure, which was formed during the periods when the seeds of the development in question were thrown and the transformation took place, through the movie "Ikiru" and the novel "Castle".
\end{abstract}




\section{INTRODUCTION}

The world has shifted from the "old" bipolar political structure to a unipolar and/or multipolar structure and in this transformation process, "whatever is left of the past" has started to change its meaning and content. Globalizing, neo-liberal language has become dominant all over the world. In this context, while the terminology of the globalization ideology has become the only criterion for the meaning and evaluation of all fields related to state administration, one of the concepts affected by this development has been "bureaucracy".

Bureaucracy emerged with the phenomenon of the state; although it has reached different dimensions in various cultures over time, its basic principles have remained valid (Baransel, 1979:162, Abadan, 1959:13). In this study, firstly, the definition of bureaucracy is made based on the historical development and change of bureaucracy handled in parallel with bureaucracy theories. First of all, Marx's views, which explain the essence and functioning of the bureaucracy in parallel with the process of capitalization, will be analyzed, then Weber's perspective, which takes the bureaucracy as a rational form of organization based on laws and rules, will be revealed, in addition to these theories, elitist bureaucracy theories will be evaluated which focuses on ruling and ruled class. Also, it is analyzed neoliberal theories which aim to approach bureaucracy within the framework of private sector organization strategies, and neo-Marxist theories which approach the bureaucracy analysis in the context of the relation between capitalism and the state. Based on the perspectives of these theories, the term "bureaucracy" is examined as a management system that surrounds the individual in the light of existential inquiries at a higher scale, and be examined with a red tape aspect at a lower scale on an analysis of Kurosawa's movie "Ikiru" and Kafka's novel "Castle".

\section{SCOPE AND METHOD OF THE STUDY}

In the study, primary source works, which are Franz Kafka's own works, were scanned. The phenomenon of "bureaucracy" is the subject of research through the novel "The Castle" (Das Schloss) and Japanese director Akira Kurosawa's 1952 movie Ikiru (To Live). As a result of the literature review, the "definition of bureaucracy" and "bureaucracy theories" were examined and the book Castle and the movie Ikiru were analyzed with the help of the conceptual tools provided by the study, and the forms of bureaucracy in different societies were revealed by using the method of content analysis.

The scope of the study is limited to the study of the novel and the movie mentioned by considering the basic assumptions of bureaucracy theories in the context of mutual relation between the individual, society and bureaucratic organization. While examining bureaucracy theories, it is accepted that different societies are shaped by specific social dynamics, and the ongoing processes of bureaucracy and the reciprocal interaction of social actors are evaluated within the framework of the mutual relationality of economic, political or social actors.

In this study, the descriptive method, which is one of the qualitative research methods, is used to analyze the functioning of the bureaucracy in the intermediary role of the administrative process. The bureaucratic order in which individuals live and their ontological positions such as despair, alienation, lack of communication, submission to the system are also discussed by presenting Kurosawa's film Ikiru and the Castle novel by Kafka.

\section{THE ORIGIN AND DEFINITION OF BUREAUCRACY}

The word "bureaucracy" was first used by Vincent de Gournay, a physiocrat, in France in 1745. "Bureaucracy" consists of "burra" (dark-colored fabric) in Latin and "kratos" (sovereignty, governing) in Greek (Abadan, 1959:7). It is stated that the "bureaucracy" term stands for "bureau", which indicates "a typing desk covered by dark-colored fabrics" and also bureau term has been used as "a kind of public office where civil servants work" since the $18^{\text {th }}$ century (Abadan, 1959:7).

In the $18^{\text {th }}$ century, the "bureaucracy" term did not only describe a regime that bureaucrats played a significant role in political life. Baron de Grimm, a French philosopher, claimed that offices were not formed to provide public interest; on the contrary public interest was formed to help bureaus to dominate. Therefore, bureaucracy term in the $18^{\text {th }}$ century referred to bureaucrats benefiting from the power (Heper, 1983:290, Abadan, 1959:7).

According to Michel Crozier, bureaucracy term has three meanings. At first, the term implied "governing via offices, in other words managing via state bodies adhered to a highly powerful central authority and formed by 
assigned and stratified officials". Second, bureaucracy implied a certain type of structure having the qualifications such as being applicable to all organizations within time, being normalized of all tasks and methods, and also not being identified of authorities with individuals. Third, bureaucracy acquired a disparaging meaning in colloquial usage, which meant performing the job slowly, always doing the same things, making barriers for people, being inhumane, avoiding requirements, and the situations causing quite deep deprivations for both employees and beneficiaries of bureaucratic services (Eryılmaz, 1993:31).

\section{THEORIES OF BUREAUCRACY}

Theories of bureaucracy are classified basically as Marxist, Weberian and Elitist approaches. Also based on these theories we can mention neoliberal and neo-Marxist theories.

\subsection{Theory of Marxist Bureaucracy}

The theory of Marxist bureaucracy explains the core and functioning of bureaucracy in parallel to capitalism. In regard to the general approach of the theory, bureaucracy is a phenomenon addressed in the context of governance. Accordingly, bureaucracy does not exist in the society in which state does not exist yet (Mouzelis, 2003:11). The Marxist theory considers the state as an institution protecting the interests of the dominant class. The state did not exist from all eternity, but it emerged at a certain period of economic affairs when society inevitably required to be divided into classes (Mouzelis, 2003:12).

The state is the instrument of domination of one class over another and it does not have the qualification of defending the common interest of the society. The natural result of this qualification is that bureaucracy itself does not constitute a class although it protects interests of the dominant class. It is a sui generis social group, being the instrument of domination of one class over another. Therefore, it aims to maintain pressure of one class over another and justify this relationship, doing this not clearly but by hiding the existing situation or showing it differently than it is. In this context, it can be concluded that the state functions to hide the hegemony of one class over another by creating an illusion as it undertakes the duty of serving the public (Heper, 1983:293-294).

The "alienation" of the individual in this system of exploitation from the system he is in is one of the important arguments of the Marxian theory and is a phenomenon inherent in the capitalist socio-economic order. Bureaucracy is also a part of the process that creates alienation. When the bureaucracy turns into a mysterious, almost divine and autonomous power, which is increasingly withdrawn, people feel helpless and helpless in front of them, it also controls the lives of individuals; however, it is inevitable that they become alienated against this closed structure that they cannot control themselves (Mouzelis, 2003:13)

There is a state of alienation within the bureaucracy itself. In fact, bureaucrats who are unaware of the nature and oppression of the function they fulfill in the class structure and who are unaware of their own reality also think that it functions as a necessary and useful for the general interest of the society, and within this framework, they deeply respect and alienate the bureaucratic hierarchy, discipline and authority (Mouzelis, 2003:13).

In Marxist theory, the existence of bureaucracy depends on the existence of the capitalist class to which it belongs. In other words, the disappearance of the capitalist class means the disappearance of the state and bureaucracy. Just as the state has necessarily appeared at a certain period of history, it will disappear in the same way; so bureaucracy will also turn into an unnecessary institution (Fişek, 2005:109).

The most significant criticism to the Marxist theory was raised by Rizzi, a Marxist philosopher. According to Rizzi, Soviet bureaucracy has formed a new class exploiting and dominating the proletariat. Means of production have belonged to state and so to bureaucracy, not to the public (Fişek, 2005:116).

\subsection{Theory of Weberian Bureaucracy}

Weber considers bureaucracy primarily as a "form of organization and management" (Baransel, 1979:166). According to Weber, people working together in large groups are organized and managed in accordance with "rational principles" after exceeding certain amounts. These "principles" are the same for all large groups under a common authority (Baransel, 1979:167). 
From a Weberian perspective, bureaucracy is built on the separation of politics-administration and it functions as a technical tool. Weber opposes the bureaucracy to be a policy-determining institution with political responsibility. Therefore, the theory of Weberian bureaucracy searches for a balance between keeping bureaucracy away from political influences, which enables it to function on the basis of productivity principle, and preventing bureaucracy to be a tool of the power rivaling the politics as a result of extreme strengthening (Weber, 1998:83).

According to Weber, bureaucracy is a system of law and rules rather than a human system. As an institution uniting society, the state, whose responsibilities and authorities are regulated by the law based on the codes and rules, uses its sovereignty and force-use power through public bureaucracy, a systematic management tool (Weber, 1998:290-292).

Weber has not analyzed bureaucracies experimentally but as an "ideal type" emerging from the most characteristic bureaucratic qualifications of all known organizations (Gülmez, 1975:59). Structural and functional qualifications of Weber's ideal-type bureaucracy (Gülmez, 1975:51-53; Weber, 1998:192; Abadan, 1959:55-58) can be briefed as follows; determination of official tasks and rules and predetermination of rules and restrictions on the use of authorities that will enable these tasks to be implemented; the hierarchy of the authority; management based on written documents; specialization and thus increased efficiency; being nonpersonal; career structure; performance-based promotion; rules-based system; separation of public and private life; elimination of arbitrariness in organizational behavior.

To be able to understand better Weber's thoughts on bureaucracy, it will be useful to emphasize the concepts of power and authority (Baransel, 1979:168). Accordingly, "power" means that one can make his own will realize despite the others' resistance. "Authority" means that an order imposes on someone a duty of obedience. Weber states that "legitimacy" is derived from three sources. There are mainly three types of authority as "traditional", "legal" and "charismatic" depending on the legitimacy they are based on.

In the "Traditional Authority" type, political power takes its legitimacy from the traditions that have been established since very old times and the belief in the sanctity of these traditions. The traditional mandate is personal and is based on innate status; power and orders are legitimate if they do not contradict the traditions (Baransel, 1979:169). In Weber's thought, the traditional authority is determined as "patriarchal" and "patrimonial" in two types. In patrimonial authority, society has become a little more complicated. There is a certain level of decomposition in management. In the traditional patriarchal authority, the administrative staff has been occupied by relatives and loved ones of the manager (Y1lmaz, 1997:396). "Charismatic Authority", on the other hand, is the authority resulting from absolute loyalty and trust in a person, belief in his heroism or superior qualities (Eryılmaz, 1993:39). It is a social and psychological phenomenon and is based on a certain belief in the superior qualities of the leader. The "Legal Authority" type depends on believing in the validity of laws and functional authority based on rational rules (Gülmez, 1975:59). People obey the law because they believe that it is made according to a procedure that is accepted as appropriate and correct by those who govern and ruled (Baransel, 1979:169). According to Weber, the legal authority is the sovereignty of the modern civil servant and the political power holders (Baransel, 1979:169).

Weber's model has been subjected to criticism as it is a methodological model and does not fully reflect social reality (Fişek, 2005:30); thus, bureaucracies do not function rationally and do not include informal relationships, disregard of expertise of civil servants' dysfunctioning of official hierarchical authority, disregard cultural differences, also there are other issues about this model such as strict adherence to rules, conservative aspects that can lead to inefficiency and weaken enterprise power, addressing to industrial society more than information society.

The bureaucracy is expected to keep individual factors and behaviors to a minimum and to eliminate the possibility of arbitrariness in organizational behavior, thereby maximizing efficiency. However, since bureaucracy emerges as a result of rationalization and rationality requires the existence of strict regulatory rules that keep personal breakthrough-power and creativity to a minimum, the Weberian model of ideal bureaucracy reduces the individual to a certain small part of a giant machine. This situation, which reflects the technical superiority of the bureaucracy, is also the main source of Weber's anxiety about bureaucracy (Fişek, 2005:7576).

Robert Merton, who examined the bureaucratic theories from a Weberian perspective, states that while the characteristics of bureaucracy such as adherence to rules and official documents create a sense of trust in the public, the phenomenon of "bureaucratic personality" emerges in public organizations; that is, public officials strictly adhere to bureaucratic rules and make these rules a purpose rather than a tool (Nohutçu, 2015:54). 
Again, Alvin Gouldner, from the same school, emphasizes that by introducing new rules and increasing the control mechanisms to eliminate conflicts between public officials and the public, a vicious circle has actually emerged by strengthening the bureaucracy (Nohutçu, 2015:54).

In addition, if we analyze Weber's approach to bureaucracy in terms of its relationship with democracy; Weber approaches the issue from two angles. When the problem is handled from an "individual" perspective, the fact that individual behaviors gradually come under the rule of regulatory rules affected by the organization in which they are located and thus the individuals lose their ability to affect it, increases the efficiency of the organization in one way and leave individuals without words on a subject that directly concerns them with its anti-democratic aspect. On the other hand, when the problem is approached from an "organizational" point of view, it is seen that a contradiction arises between the tendency of bureaucratic structures to gradually expand their scope of duties and the ability of bureaucrats to effectively control their areas of duty. This contradiction, which becomes more evident by bringing the person who can do his/her duty best and thus making that person in a way indispensable, that is, less responsible and less controllable, institutionalizes the practice that has proven technical superiority in one aspect, and it makes the administrative structure insulated from individuals' democratic control in its anti-democratic aspect (Waldo, 1952:85-90).

According to Weber, the bureaucracy, which is the product of the need to do every job in the best way and therefore, considers the general benefit of society, tends to move away from democracy with the effect of the characteristics that make it "the best" in Weberian line of thought (Fişek, 2005:76).

Weber thinks that only political leaders with certain qualities can stop this development. In the legal bureaucratic authority type, the ideal officer should be a person who is objective, aware of his duty and exercises his powers within the limits of the law. However, in bureaucratic institutions in modern societies, deviations from bureaucratic principles such as political neutrality and exercising authority limited to laws are encountered. Although, with the change of political power, the replacement of high officials with new ones without giving much importance to their expertise seems like a solution, according to Weber, even this is not a way out; because modern democracy will eventually turn into bureaucratic democracy (Heper, 1973:35).

In the legal bureaucratic authoritarian type, politicians must have certain qualifications so that the political power is not completely taken over by the bureaucracy and the bureaucratic administration can be kept under control. According to him, the qualifications of the politician should be based on a triple basis: ambition for success, sense of responsibility, and farsightedness (Ergun ve Polatoğlu, 1992:55).

Politicians are expected to believe in any one or more moral ideal like national, humanistic, social, moral, cultural, religious and so on and strive for the realization of that ideal or ideals. However, if this ambition of success in the service of belief in a certain thing does not guide one's actions at the same time under the guidance of the "sense of responsibility", it is not enough to make a person a politician. The politician must bear the responsibility for the predictable consequences of his actions, and besides these basic qualities, he must also have some other characteristics: for example, not to be flattering and not demagogy; not getting above oneself; not only seeing politics as a livelihood profession but also living in politics (Ergun ve Polatoğlu, 1992:55).

Weber's ideal type of politician is a person of "extraordinary qualities" that is rare in this world. To put it more accurately, Max Weber enumerates the qualities of the modern charismatic leader. In Max Weber's opinion, "modern charismatic leaders" will be able to prevent the ever-developing bureaucracy from restricting human rights and freedoms one day. Weber's model of legal-rational bureaucracy, which is one of the most inspired the theory of "Comparative Public Administration" theorists, has remained indispensable for many years. It has been recognized that the legal-rational bureaucracy model is the bureaucratic type of modern industrialized society (Heper, 1973:36).

\subsection{Theory of Elitist Bureaucracy}

The theory of elitist bureaucracy clearly differentiates from both Marxist and Weberian theories. Its most distinctive element is that elitist theory does not directly deal with reasons for being of bureaucracy and its functions in social life, but it deals with political and administrative elitists and these elitists' power and efficiencies in managing the society and their results. Technocracy, giving importance to knowledge and technical expertise to be effective in administration, constitutes one of the important arguments of this theory (Tortop et al., 1993:222). 
Robert Michels, one of the leading representatives of this theory, describes bureaucratization, growing day by day in modern societies, as a factor preventing the realization of democracy in his analysis, which he specifies as the "Iron Law of Oligarchy" (Ergun ve Polatoğlu, 1992:63). According to Michels, all organizations in democratic form deviate from the democratic aims and principles in time and tend to a particular group. He makes his point clear by saying "Whoever talks about organization means oligarchy" (Eryllmaz, 1993:24).

Bruno Rizzi is one of the authors influenced by socialist thought, even considering himself as Marxist at first, but later denying it and taking part in elitist thought (Fişek, 2005:79). According to Rizzi, the Soviet bureaucracy has become a new class that exploits the working class (proletariat) as the capitalists do (Mouzelis, 2003:31). In the Soviet Union, means of production were not socialized, but only nationalized. Accordingly, the means of production do not belong to the public, but to the state and ultimately to the bureaucracy that owns the state. In the final analysis, some elements in the bureaucracy like technicians, directors and experts, etc. exploit the proletariat and collectively seizure surplus labor. Therefore, in Rizzi's opinion, the state is not a tool of ruling class but the ruling class itself in this type of bureaucratic exploitation (Mouzelis, 2003:31).

Stating that an authority called "government" exists in all regular societies, Gaetano Mosca, an Italian philosopher, divides the society as "ruling class" and "ruled class". Mosca describes ruling class as a group benefiting from the power, holding power monopoly, executing all kinds of political functions, and being few in number. The ruled class is a group facing arbitrary treatment more or less, ruled by the first group by force and being many in number. Mosca identifies the bureaucracy that monopolizes wealth and military authority as "bureaucratic absolutism" and states that this regime is "despotism"(Ery1lmaz, 1993:22).

One of the people introducing the "elite (eligible)" term to political science first was Vilfredo Pareto, an Italian sociologist. It can be said that Pareto was largely under the influence of Mosca's opinions. Pareto dealt with Mosca's "ruling class" concept, developed it and tried to put it on a broader sociological basis. For this, he used the concept of "elite" as a theoretical research tool. He defines the class formed by the combination of the best in their own fields of activity as the "elite". Therefore, Pareto states that all societies are divided as "elite" and "non-elite" after he describes the elite concept. Then, he divides the elite into "ruling elite" and "non-ruling elite". He also says that "There will always exist a ruling elite in the society and the society will always be based on the division of "mass-elite" (Kapani, 2001:113-115).

One of the members of the "ruling elite theories" is James Burnham, an American philosopher and political theorist. According to Burnham, there has been a transition from capitalism to a social structure that can be called "managerial society". In his theory, that is "managerial revolution theory", in the political environment of the Second World War, the world is experiencing a transition period moving from capitalism to a social structure called "managerial society" similar to the transition from feudalism to capitalism in the early modern period of $16^{\text {th }}$ and $18^{\text {th }}$ centuries. Accordingly, the managerial revolution creates a new ruling class, as in the bourgeois revolution, but this time the specific function of whom is to "manage and coordinate" industrial production. The specific function of "managers" here is "managing and coordinating" industrial production. This function is no longer performed by capitalists. Burnham claims that large-scale industries and giant corporations form a separate ruling class and take control of their means of production. The specifically developed form of this administrative society is state ownership of the means of production and administrative control of the state. Sweezy reveals his criticism of Burnham's "ruling class" theory by stating that when new individuals gain control over the means of production, it must be analyzed well whether it is a new class or new personnel (Sweezy, 1942:4-10).

\subsection{Neoliberal Theories}

Although it is based on the rejection of the Weberian theory, the main logic is the same; in other words, bureaucracy is modeled within the framework of private sector organization theories. While addressing the bureaucracy problem in terms of "public bureaucracy", its solution proposals are "organization-private sector centered".

\subsubsection{The New Public Management Approach}

The "New Public Management Approach" has started from the assumptions that the bureaucratic organization should have more flexible mechanisms to respond to the demands of the citizens and that the classical understanding is no longer sufficient to solve the problems (Hughes, 2017:67). Then it has risen on the basis of 
the idea that the public bureaucracy will be more efficient if it takes advantage of the private sector strategies. Believing that the financial crises occur because of ineffective use of public expenditures has also had an effect on claims that these expenditures should be scrutinized (Hood, 1991:6-8). Since there are no competition conditions in the provision of public services, "the provision of services from the market" and "decentralization" has been brought to the agenda with the claim that the service will be provided from the closest place to the people who will benefit from these services. Within the scope of evaluating the quality of the service received, "focusing on the result and the output" also has been brought to the agenda (Larbi, 1999:14-20).

The spread of "business administration" practices in public administration has been supported by other factors beyond the crises experienced. Among these factors; the debate on the extent to which the state will intervene in the production, accumulation and distribution regime with the institutions and practices of it (Aktan, 2003:133), the rise of neoliberalism in the 1980s, the demands and expectations of the masses for the taxes they pay seeing the lives of other people as examples through the developments in science and technology and the international institutions' willing to lend money to the developing countries putting these practices as a condition (Akın, 1998:92).

"New public administration movement", which started out with the claim that it is a synthesis of many theories, there can be said that it is the melting process of some principles in the same crucible like administrative efficiency, political responsiveness, economic efficiency, social justice, customer focus, participation, especially the participation of disadvantaged groups, determining the goals in the public sector, evaluating the results, performance measurement, the emphasis on objectives and concepts such as flexibility, change-orientation, focusing on goals rather than institutional orientation, emphasis on localization, egalitarian approach in the distribution of services, mentioning less hierarchical analysis in internal dynamics, although goals and solutions are prioritized in the organizational structure (Frederickson, 2010:6-12).

The "innovation" of the new public administration approach is questioned by claiming that it has the same arguments as the old public administration approach and that it is only the adaptation of the old approach to today's conditions (Frederickson, 2010:6-12).

\subsubsection{Public Choice Approach}

The public choice theory emerged in the 1950s and 60s with an understanding that criticizes the political processes in America. The basic thesis of the thought led by James Buchanan is shaped on the basic concepts of the administrative system such as electoral systems, electoral behavior, political parties, bureaucracy, and the deficiencies of Keynesian views on the basis of the idea of "failure of the state", that social choice is not carried to political decision-making mechanisms. Public choice also uses the methods and tools used by economics to explain the political processes and processes of the public sector (Çoban, 2003:75-80).

Public choice theorists have stated that political man and economic man have the same characteristics. They oppose the argument that bureaucrats and politicians make decisions in a way of public interest. Public choice advocates oppose the public-private sector divergence when it comes to public benefit and public interest. Public choice thinkers who are not against the free market logic are in favor of not leaving the free market unsupervised (Aktan, 2003:52-54).

Actors playing a role in the democratic decision-making process are voters, political parties, bureaucracy and pressure groups. According to public choice theorists, each of these elements is in an effort to increase their own interests. Voters want to increase the service to be provided to them, political parties want to increase the votes and their political gains, bureaucracy demands the opportunities and reputation and pressure groups claim the interests of their group. Each actor participates in the political process in different ways, at different times, in order to achieve his interests. Due to utilitarianism, every person tends to protect himself and his family. Therefore, rational man does not consider the public interest. In this way, the activities of all these elements lead to political and economic corruption, and it is not easy to eliminate this corruption completely. The solution is to control these individuals through an institutionalized structure. The stronger the institutions, the more they will have the chance to control the individual (Çoban, 2003:80-85).

It is stated by Kaplan that the thoughts of the public, that is the state, fail in administration and it should be downsized include the following basic arguments (Kaplan, 2004); Lack of Knowledge of Rational Voters, Indifference of Rational Voters, Rent-Seeking, Vote Trade, Political Myopia, Failure to Realize the Unanimity Principle, Presentation of Public Goods and Services as a Whole, Median Voter Theory. 


\subsection{Neo-Marxist Theories}

In order to evaluate the neo-Marxist theorists' perspectives on bureaucracy, it is essential to consider the analysis in the context of the relation between capitalism and the state. These theorists take the relative autonomy of the state in the class balance approach as the basic starting point for the Marxist theory of the state. In a sense, it can be considered as an effort to form a Marxist theory of the state. To mention in general terms of the perspectives of these theorists in the context of their contribution to the analysis of the concept of bureaucracy;

Structuralist Marxist theorist Althusser critically reinterpreted the economic reductionist analysis of Marxism by addressing the state-capitalism relationship with a structuralist approach. In this respect, he has re-established the concept of "ideology" in an area independent of the economic determinist analysis. Institutions such as school, religion, army and the family are the systematic pressure apparatus of the state (Ideological State Apparatuses). The "ideology" that turns the object into a subject not only creates institutional structures but also plays an inherent role in institutional structures. In this respect, the institution of bureaucracy ensures its continuity by establishing the procedures within the administrative structure with its rules (Ricoeur, 1994:4552).

Using Althusser's structuralist Marxism approach to explain the capitalist state, Neo-Marxist theorist Poulantzas formed his theory on the fields of study such as "ruling class", "state power", "class power" based on the idea of "relative autonomy" of the capitalist state. Accordingly, the state functions as an institution that ensures social unity in a relatively autonomous position against the economic level. However, the capitalist state is a social formation created by historical conditions and has no instrumental role in the formation of a new historical bloc (Poulantzas, 1969:73).

Miliband emphasizes that Poulantzas overestimates the structural constraints of the capitalist system, which will drag the bureaucratic elite to a passive position, leading to the conclusion that they have no activity at all as if they were mere bearers of the structure. According to Miliband, one of the representatives of the instrumentalist approach of the state, the power of monopolies is intertwined with the power of the state, and capitalist class members form the ruling class together with the bureaucratic elite by taking part in the state and government apparatus (Miliband, 1970:53-60).

\section{IKIRU (TO LIVE) ${ }^{1}$}

The life of Kanji Watanabe, giving existential effort in the modern bureaucratic system as the "Chief of Public Relations Department" is shown in this movie directed in 1952 by Akira Kurosawa, one of the major directors of the Japanese movie sector.

The hero of the movie, Kanji Watanabe, works as the chief and senior-level manager of the public relations department of the municipality; in other words, he preserves his position. The best way of preserving the position is by doing nothing. In brief, our hero is not managing his department but preserving the status quo in the municipality where he has served for 30 years.

Photograph 1. The Hero of the Movie "To Live (İkuru)", Kanji Watanabe is at Public Relations Department of the Municipality

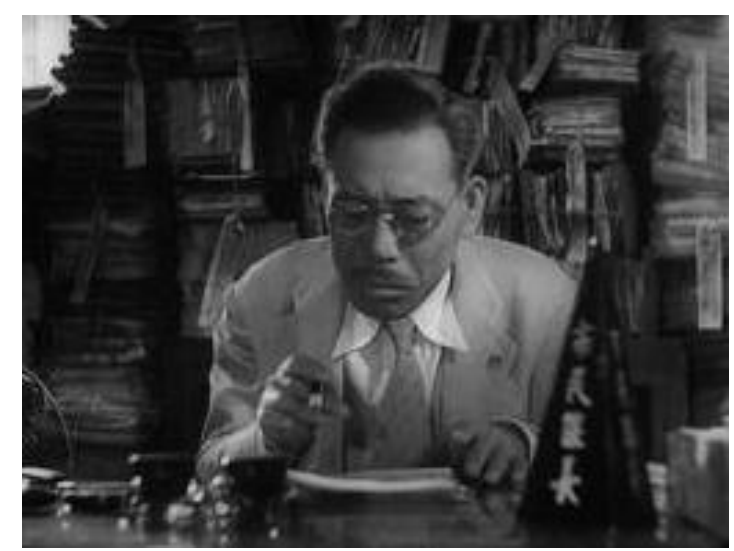

Source: http://www.janusfilms.com/films/1056 (Access Date: 16.06.2020).

1 "Ikiru", the Japanese drama film directed by Akira Kurosawa in 1952, is the original name of the film which means "to live" in English. 
The movie starts when a group of women residents in the neighborhood asks the municipality to fix an empty area where dirty water accumulates and to make a playground instead. Saying "it is not our job", Kanji Watanabe immediately leads women to the engineering department. In fact, he gets rid of them, which starts a completely-tragicomic vicious circle. Each department, which women apply for, leads them to another unit with an explanation in its own way. In the end, women, walking around the town hall, visit the deputy mayor, and then come back to the public relations unit, where the vicious circle has started. As a last solution, Watanabe gets a written petition and puts it into a high pile of paperwork; in other words, he preserves his position skillfully again by doing nothing. It indicates the meaningless processes of the bureaucratic system dramatically.

Photograph 2.Kanji Watanabe is in a Great Shock After Learning From The Doctor That He Has Stomach Cancer

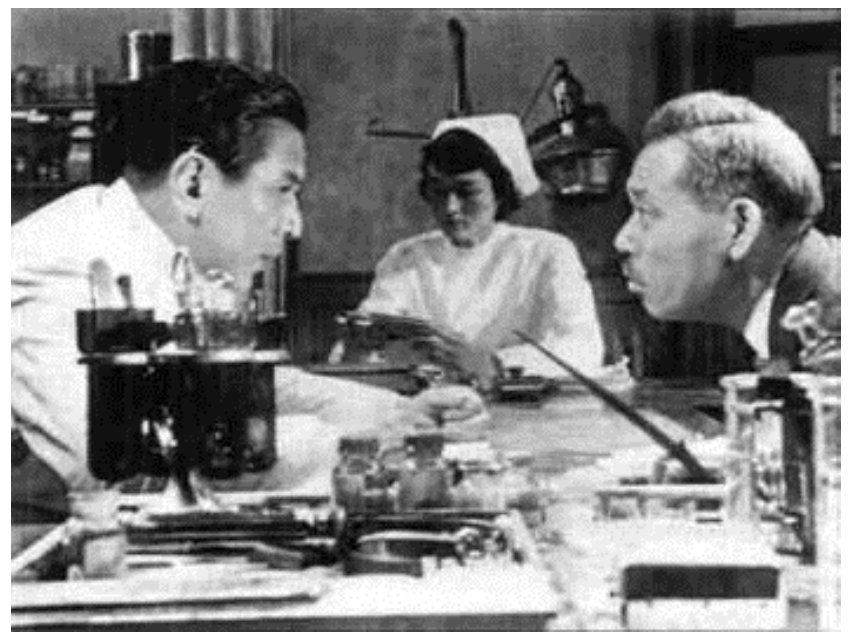

Source: http://www.janusfilms.com/films/1056 (Access Date: 16.06.2020).

The chief of the department, Watanabe, being about to achieve the record of coming to work for 30 years without any permission, is in a great shock after learning that he has stomach cancer and then he quits going to work. Following the great shock, our hero wakes up from a deep and long-term sleep like a mummy, called by his subordinates. Feeling too close to death, Watanabe gets lonely day by day and loses his motivation; thus he starts to search for the meaning of life.

Photograph 3.Kanji Watanabe is With His Colleague From The Municipality. He Admires Her Being Full of Life

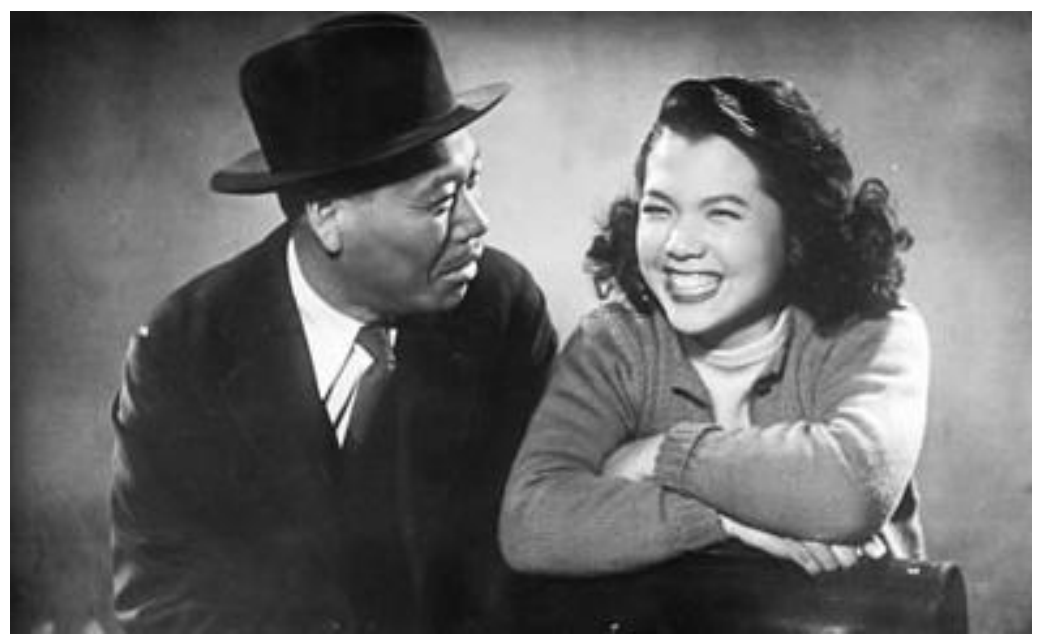

Source: https://movierdo.com/akira-kurosawas-masterpiece-ikiru-1952-review-analysis/ (Access Date: 21.07.2020).

He continues to search for it by making friendship with a young lady officially, working as his subordinate in his department. He thinks that she is the only one having the energy of life. The only thing he needs to learn from her is how she can be full of life. In the meantime, both his family and officials at the municipality spread lots of gossip about Watanabe. Saying nothing to his family and colleagues about his illness, the department chief discovers the meaning of life after all. 
Coming back to his office in colleagues' surprised looking, Watanabe immediately finds the petition submitted by women for the playground. Until his death, he insists on making the playground and gets in contact with all units in the municipality. He even dares to fight with his superiors. Watanabe, whose struggle for this little playground becomes legendary, passes away after 5 months.

During the funeral held after Watanabe's death, his colleagues discuss how he has changed in time, on the basis of his struggle for making the park and how the bureaucratic system itself has changed as well, and how they have been overwhelmed and trapped by the system, which indicates a self-criticism.

Comparing themselves to Watanabe and making an assessment, one official at the municipality faces himself and the bureaucratic system itself in fact and says; "...before working at the municipality some of us were good, but all, including myself, started to change while working". Another one says; "you do not need to do anything there. Doing something means doing nothing in fact. We are expected to seem as if we were doing something but doing nothing in fact". These expressions are so important that they indicate the degenerating effect of the bureaucratic system.

Watanabe's colleagues at the municipality get surprised at his persistence, effort, and determination in his fight for making the playground. They discuss if his individual effort has surpassed the bureaucratic system. Another opinion opposes that individual efforts of Watanabe do not make sense since bureaucracy functions as an integrated system; therefore he cannot surpass it and if there is a success, it is not achieved by only one individual but by all. It makes us think about the meaning of the existential struggle of Watanabe.

One of the officials says; "When looking back, does this struggle make any sense? He was crazy". Another official replies to him; "the main point is that the World means darkness if his struggle does not make a sense", which profoundly and dramatically presents how the bureaucracy works.

\section{THE CASTLE (DAS SCHLOSS) ${ }^{2}$}

Before starting to analyze the Novel of Castle, we would like to mention the author of the book Franz Kafka briefly. As one of the pioneers of Modern German Literature of the $20^{\text {th }}$ century, Franz Kafka, who was born in Prague in July 1883, can be described as an author who has a vision ahead of his time, narrating both in a realistic and fantastic way the crises and loneliness of western society in the process of industrialization and modernization. Considering that Kafka himself also worked as a lawyer for fourteen years in the Workers Accident Insurance Agency, the fact that he experienced challenges of bureaucracy in person makes us think that the novel bears traces from himself.

The novel is fictionalized around a castle, village, and cadastre official assigned in the castle. In the novel, while the castle symbolizes power, state, authority and bureaucratic management, the village represents ruled people. The hero of the novel is called " $\mathrm{K}$ ".

In Kafka's novel, which we can describe as the ironic expression of the bureaucracy's resistance against power, description of the location materialized as the conceptualization of castle, indicates an environmental plan making someone confuse his way in his effort to reach out to unreachable high-ranking officials in fact, also indirect means, nonsense and irrational processes of bureaucracy. From this aspect, bureaucracy is conceptualized as irrational processes, not as rational processes of the Weberian mind.

That villagers always follow K. and hesitate to adopt him in their own lives leads K. to struggle for existence and accept unreasonable contexts. As he tries to reach the castle, he constantly goes back to the beginning and gets in a vicious circle. Finally, getting tired, he is forced to accept the rationale of the castle.

With a reference that the appointment and promotion of all civil servants in the bureaucratic system depend on certain principles, in the novel, K. tells the headman of the village that he was appointed as a cadastral official. The headman of the village states that there is confusion because they have told the officials that they do not need a cadastral official; which causes a complicated correspondence process. The following words of the headman enlighten us about the complexity of the bureaucracy; "At such big authorities like earldom, some units can sometimes take different decisions and none of them knows about the other's" (Kafka, 2014:67).

2 The original name of the book is "Das Schloss" in German. 
As stated in Weberian bureaucracy, relations between village and castle are also a system of law and rules rather than a human system. Indeed, in the novel, when regarding the relationship with the castle, villagers can act irrationally in the name of adherence to the rules and exclude those who act in a contrary manner.

If we talk about Weber's concept of "specialization" in his understanding of bureaucracy, we need to look at the following words of the woman named Olga, while speaking to K., the main character of the novel, which clearly indicating bureaucratic specialization of the castle's officials.

"Officials are highbrowed people, but their culture is unilateral. If one official hears one word regarding his own profession, he can uncover the whole chain of thought on the other side.

However, he can listen to you but understand nothing if you tell him something regarding another department for hours" (Kafka, 2014:242).

Directing K. to an official on his own work continuously and attaching importance for the intolerance of authority failures (Kafka, 2014:296) highlight the strict separation of authority in the bureaucracy.

The hierarchical separation between the castle and the village and the organization seeming both very close and far demonstrate the gap between the public and the administration. Furthermore, that K. communicates with high-ranking officials in the castle only via messengers and that he has troubles in reaching out to high-ranking officials indicate the hierarchy of superior-subordinate of the existing bureaucracy between the managers in the castle and villagers.

Appreciating K.'s work and wishing it to continue in the same way, the letter, brought by messenger Barnabas and sent by Klamm, the high-ranking official in the castle, reminds us of the correspondence codes, resembling printed correspondence procedures in the bureaucracy, including general expressions without understanding the nature of the subject and being written just to write.

Referring to the Marxist concept of alienation, in the close and oppressive system between the castle and the village, that $\mathrm{K}$. is constantly highlighted by villagers as a foreigner, K. cannot understand the cowered, objectified, inconsistent and irrational behaviors of the villagers against the authority, and finally, K. adapts and obeys to their system to be adopted by villagers bring to mind the officials turning to a machine in bureaucracy's impersonal rules.

With the feeling of alienation, K. comes closer to the Barnabas family excluded by villagers since they have not bowed to the authority. As a result of this, he is excluded too. Therefore, K. is forced to adopt the logic of the system, which causes his personality to be lost in the system.

\section{CONCLUSION}

In this article, through Kafka's book "The Castle" and Kurosawa's movie "Ikiru" it is analyzed the functioning of the bureaucratic system and how the phenomenon of bureaucracy changes the individual and society focusing on the existential struggle of the heroes of both movie and book against bureaucracy's alienating aspect.

In Kafka's novel "The Castle", the place setting, reminiscent of the feudal era castle and surrounding villages, is a metaphoric expression of the bureaucratic order in today's modern society. The movie "Ikiru" corresponds to the urban life in the period of strong central bureaucracy which developed as an important reflection of the modernization process experienced by the Japanese society, after World War II after the Meiji Restoration, which started in Japan in 1868.

Both the main character of Kafka's book "The Castle" and the hero of the movie "Ikiru", Watanabe, as officers of the bureaucratic order, in an effort to find a way out within their cycle of producing red tapes such as differentiation of authority, specialization, recording, filing, and reliance on written procedures they are alienated from the society they live in.

The gap between the ruling class and the ruled class of Gaetano Mosca is very clear between the Castle and the village. Its winding roads, its dominant position at the high point, the inaccessible spatial structure of the castle clearly reveal the separation of the people and the administration. The peasants are strange, gossiping people but obedient to the castle and on the other hand are brutal against each other. In the movie Ikiru, the officers of the bureaucratic order are as obedient to the logic of the system as the people living in the city. 
Hope, as the main theme in the movie Ikiru, is always the opposite of the gloomy environment, nothingness, and meaningless processes in Kafka's novel Castle in the struggle to get rid of the bureaucracy, which focuses more on solutionlessness rather than the solution.

While K.'s bow to the system of the castle, Watanabe has found his own way to invert the system from the inside, to discover the freedom path in the cracks of the system. In this sense, Watanabe has found the meaning of life in his existential struggle by escaping through the cracks in the system and by creating solutions at any cost in the unsolvable system.

\section{REFERENCES}

ABADAN, Nermin (1959), Bürokrasi, Ankara Üniversitesi Siyasal Bilgiler Fakültesi Yayınları, Ankara.

AKIN, Cengiz (1998), “Kamu Yönetimini Yeniden Düzenleme İhtiyacı”, Türk İdare Dergisi, S.419, ss.89-100.

AKTAN, Coşkun Can (2003), Değişim Çağında Devlet, Çizgi Kitabevi Yayınları, Konya.

BARANSEL, Atilla (1979), Çağdaş Yönetim Düşüncesinin Evrimi, İstanbul Üniversitesi Yayını, İstanbul, Cilt.1.

ÇOBAN, Ali R. (2003), “Kamu Tercihi Teorisi”,Çağdaş Kamu Yönetimi I (Ed. Muhittin Acar, Hüseyin Özgür), Nobel Yayıncılık, Ankara, ss.75-97.

ERGUN, Turgay ve POLATOĞLU, Aykut (1992), Kamu Yönetimine Giriş, TODAİE Yayınları, Ankara.

ERYILMAZ, Bilal (1993), Bürokrasi, Anadolu Matbaacıllk, İzmir.

FIŞEK, Kurthan (2005), Yönetim, Paragraf Yayınları, Ankara.

FREDERICKSON, H. George (2010), "Social Equity and the New Public Administration", Social Equity and Public Administration, M.E. Sharpe, ss.3-23.

GÜLMEZ, Mesut (1975), “Weber ve İdeal Tip Bürokrasi Anlayışı”,Amme İdaresi Dergisi, S.8(1), ss.47-75.

HEPER, Metin (1973), Modernleşme Bürokrasisi, Sosyal Bilimler Derneği Yayınları, Ankara.

HEPER, Metin (1983), “Bürokrasi”, Cumhuriyet Dönemi Türkiye Ansiklopedisi, İletişim Yayınları, İstanbul.

HOOD, Christopher (1991), “A Public Management for All Seasons?”, Public Administration, S.69(1), ss.319.

HUGHES, Owen E. (2017), Public Management and Administration, An İntroduction, Palgrave, Macmillan, $5^{\text {th }}$ Ed.

KAFKA, Franz (2014), Das Schloss - Şato (Çev. Regaip Minareci), Türkiye İş Bankası Kültür Yayınları, İstanbul.

KAPANİ, Münci (2001), Politika Bilimine Giriş, Bilgi Yayınevi, Ankara.

KAPLAN, Ersin (2004), "Kamu Tercihi Teorisinde Karar Alma Süreci ve Bu Süreci Etkileyen Aktörler", Akademi İktisat, http://www.akademiktisat.net/calisma/kamu_yonetim/kamu_tercih_ekaplan.htm (Access Date: 27.08.2020).

KUROSAWA, Akira (1952), “Ikiru (to Live - Yaşamak)”, Film, Toho (Japonya).

LARBİ, George A. (1999), The New Public Management Approach and Crisis States, UNRISD Discussion Paper, Geneva.

MILIBAND, Ralph (1970), "The Capitalist State: Reply to Nicos Poulantzas", New Left Review, S.1(59), ss.53-60.

MOUZELIS, Nicos P. (2003), Örgüt ve Bürokrasi, Modern Teorilerin Analizi (Çev. H. Bahadır Akın), Çizgi Kitabevi, Konya.

NOHUTÇU, Ahmet (2015), Kamu Yönetimi, Savaş Yayınevi, Ankara.

POULANTZAS, Nicos (1969), "The Problem of the Capitalist State”, New Left Review, S.1(58), ss.67-78. 
RICOEUR, Paul (1994), “Althusser's Theory of Ideology”, Althusser (Ed. G. Elliott), Cambridge Press, Cambridge (UK), ss.45-52.

SWEEZY, Paul M. (1942), "The Illusion of the Managerial Revolution", Science and Society, S.6(1), ss.1-23.

TORTOP, Nuri ve İSBİR, Eyyüp, Günay (1993), Yönetim Bilimi, Yarg1 Yayınları, Ankara.

WALDO, Dwight (1952), "Development of Theory of Democratic Administration", The American Political Science Review, S.46(1), ss.81-103.

WEBER, Max (1998), Sosyoloji Yazıları (Çev. Taha Parla - Ed. H.H.Gerth, C. Wright Mills), İletişim Yayınları, İstanbul.

YILMAZ, Aytekin (1997), “Türkiye’de Yönetimde Yetersizlik ve Sorunlar”, Yeni Türkiye, S.3(13), ss.394-404.

http://www.janusfilms.com/films/1056 (Access Date: 16.06.2020).

https://movierdo.com/akira-kurosawas-masterpiece-ikiru-1952-review-analysis/ (Access Date: 21.07.2020). 